CORRECTION

\title{
Correction: Further evidence of involvement of TMEM132E in autosomal recessive nonsyndromic hearing impairment
}

Khurram Liaqat, Shabir Hussain, Muhammad Bilal, Abdul Nasir D, Anushree Acharya, Raja Hussain Ali, Shoaib Nawaz, Muhammad Umair, Isabelle Schrauwen (D), Wasim Ahmad and Suzanne M. Leal

(C) The Author(s), under exclusive licence to The Japan Society of Human Genetics 2021

Journal of Human Genetics (2022) 67:181; https://doi.org/10.1038/s10038-021-00951-9

Correction to: Journal of Human Genetics https://doi.org/10.1038/ s10038-019-0691-4, published online 28 October 2019

The article "Further evidence of involvement of TMEM132E in autosomal recessive nonsyndromic hearing impairment", written by Khurram Liaqat, et al., was originally published electronically on the publisher's internet portal on 28 October2019 without open access. With the author' decision to opt for Open Choice the copyright of the article changed on 11 June 2021 to (c) Author(s) 2019 and the article is forthwith distributed under a Creative Commons Attribution 4.0 International License, which permits use, sharing, adaptation, distribution and reproduction in any medium or format, as long as you give appropriate credit to the original author(s) and the source, provide a link to the Creative Commons licence, and indicate if changes were made. The images or other third party material in this article are included in the article's Creative Commons licence, unless indicated otherwise in a credit line to the material. If material is not included in the article's Creative Commons licence and your intended use is not permitted by statutory regulation or exceeds the permitted use, you will need to obtain permission directly from the copyright holder. To view a copy of this licence, visit http://creativecommons.org/ licenses/by/4.0.

The original article has been corrected. 